\title{
A COMPARATIVE APPROACH OF DEALING WITH DIVERSI- TY: THE MANAGING OF IMMI- GRATION AND EDUCATION IN SPAIN AND IMMIGRATION AND HEALTH IN USA
}

\author{
Análisis comparativo del tratamiento y gestión \\ de la diversidad: inmigración-educación en España e \\ inmigracion-salud en EE.UU.
}

Antonia Olmos Alcaraz ${ }^{1}$, Raquel Martínez Chicón ${ }^{2}$ 


\section{Abstract}

This article looks at the management of cultural diversity and the construction of difference in two different contexts, Spain and the United States, and two areas of management and policy intervention, education and health. By researching these two cases with the same unit of analysis, we will show the existence of certain dynamics that create and reproduce differences and cultural-ethnic boundaries, and how these logics generate inequality between groups that are continuously essentialized. The analysis, as multisituated, and the result of ethnographic research in both contexts, takes into account that the public policies analyzed understand themselves as processes of recognition of 'cultural diversity' in terms of 'interculturality'.

Keywords: Interculturality, Education, Health, Spain, USA.

\section{Resumen}

El articulo muestra cómo se realiza la gestión de la diversidad cultural y cómo - derivado de ello-se produce la construcción de la diferencia en dos contextos diferentes, España y Estados Unidos; en dos áreas de intervención distintas, educación y salud. Siendo así, a través del abordaje de dos casos distintos y una misma unidad de análisis -la gestión de la diversidad-, mostramos cómo ciertas dinámicas están creando y reproduciendo diferencias a partir de fronteras culturales y étnicas, y cómo dichas lógicas generan desigualdades entre grupos de personas que están siendo continuamente esencializadas. El análisis comparativo ofrecido, en tanto multisituado y resultado de investigaciones etnográficas en ambos contextos, evidencia que las políticas públicas observadas en los distintos contextos mencionados vehiculan una gestión de la diversidad cultural en estos términos, identificando a la misma en tanto que "interculturalidad".

Palabras clave: Interculturalidad, Educación, Salud, España, EE.UU. 


\section{Introduction}

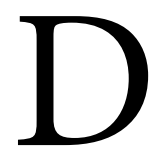

rawing on information obtained through ethnographic research in Andalucía (Spain) and California (USA), this article attempts to show how different, self-defined "intercultural" models for the management of cultural diversity may be constructing ethno-cultural boundaries that create inequality and differences between groups.

This situation forces us to reflect on how, throughout history, social-cultural categories have emerged in order to organize heterogeneities: race, ethnicity, gender, social class, among others. While nearly all of socio-cultural categories have proven to be incapable of explaining the totality of existing diversity, they have led to the emergence of other, less innocuous categories: Specifically, the construction of differences with the excuse of explaining diversity. We will examine two of these categories -race and ethnicity- in order to better understand the observed processes, through which ethnic-cultural boundaries are constructed.

\section{Races, ethnicities, borders, markers and differences}

Without trying to offer a comprehensive review of the emergence and evolution of these two categories, we will begin our analysis from an essential moment in history -really an inflection point- for understanding the true relationship between the categories of race and ethnicity: The post World War II period. In the period immediately following the war, critical positions on the use of the category of race among various disciplines (scientific, but also political and strictly academic) emerged, due to the horrors that had taken place in the name of race during the period of Nazi Germany. Within the disciplines of Sociology and Anthropology -indeed, within social sciences in general- we began to see a gradual replacement of the term "race" with "ethnicity", a term understood to be more politically correct. However, this change led to more subtle modifications in the background, and the concept of "ethnicity" adopted many of the characteristics and attributes that, until then, had been a part of the concept of "race." We must look more closely at how this change evolved in order to understand the modern use of the notion of ethnicity.

When we consider the concept of ethnicity within social sciences, we find it very complicated to define, because of the great number of approaches dedicated to its study. This is why we find definitions that come into conflict with one another; definitions that refer indistinctly to a diversity of phenomena (Devalle, 2002); and definitions that do not sufficiently define the concept (Dietz, 1999, 2012) or do so in a deficient manner that confuses ethnicity with culture.

In the first evolutionary school of Anthropology there was discussion of ethnic groups, but in a form somewhat distinct from how they are used to be, considering ethnic groups to be organizations of "primitive societies," equivalent to the nations of "developing" countries. Taylor (1996) speaks of them as a "nation of reductions," equivalent, but understood as inferior to the modern nation-states. As such, and in full observance of classical evolutionary theories, ethnic groups were characterized in opposition to "modern" nations, and described primarily by negative elements. This way of defining ethnic groups, although theoretically no more, in reality is still present in everyday discourse and, as Wieviorka (1992, $2006,2014)$ points out, we can see from how society describes ethnic groups to infer who is considered 
to be inferior. Rex (1995) agrees that when, ironically, he says "we are normal, ordinary people, they are ethnic groups." (1995: 204). Similarly, as Devalle (2002) notes, it seems that the "ethnic groups" are never "us" and always "others." This is all a product of Western-centric concepts, which serve to construct the "other" in terms of difference, inequality, and inferiority.

After World War II, as we have commented before, the use of this concept of ethnicity was modified to refer to something very similar to how races, in the evolutionary sense, were once described. The scientific community started talking about ethnicity as essential, natural, immutable, and specific to human beings: as primal qualities that we are born with (Smith, 1997) of a biological nature (Van Den Bergue, 2002) or a cultural nature (Geertz, 1973). For those who see ethnicity in terms of primal biology, ethnicities are products of genetic selection, are related to kinship and based on descent; while those who understand ethnicity in primarily in terms of elements relating to cultural, such as languages, customs and religion, etc., understand ethnicity in a essentialized way that recognizes them as natural, and as a vehicle for the production of relationships and affinities. This is how the primordialist currents, formalists, and situationists define ethnic groups, and as a result classify groups of people in the same terms of racial classifications evolutionists. That is to say, they establish hierarchical processes that are taken to be an inevitable and understood as innate and inherent to essential humanity.

Starting in the 1970s, these presumptions came into question, with the contributions made by Barth in his introductory work Ethnic group and boundaries: the social organization of difference culture (1969), which challenges the ethnic essentialism of defining ethnic groups as "social organizations of differences." At the present, moreover, the question of ethnic primordialism (Restrepo, 2004, 2013) is no longer a matter of debate in theoretical discussions, having imposed the constructivist view, which was very internally diverse, and which supports numerous theories today. However, as we will show through this text, that was not the case outside of academia and scientific communities. From the constructivist perspective, the realities that refer to ethnicities are contextual, relational, flexible, changeable and procedural while at the same time remaining stable (Restrepo, 2004, 2013). Thus, for most authors positioned within the constructivist approach that have theorized that ethnic groups are a product of two distinct processes -external ascription and self-ascription (Restrepo, 2004, 2013; Stavenhagen, 1991; Weber 2002)- its continuity would be determined by the endo-group and the exo-groups, identity and the categorization of the "others", that validate this (Dietz, 1999, 2012) identity.

Next we reflect on what the ethnographic examples show ${ }^{3}$.

\section{Methodology}

In this work we explore how, through the descriptions of two different experiences in two geographic locations and two different types of analysis (education in Spain and health in the United States), one can recognize practices that, under the name "intercultural" maintain -more or less, in both buried and expli-

3- It can be seen the researchs carried out by Fernández and García (2015), Olmos-Alcaraz (2016), Ortiz (2015) and Poveda, Jociles and Franzé (2014) in Spain; and American Public Health Association (2015), California Health Worker Alliance (2013), Centers for Medicare and Medicaid Services (2015), Figueroa and Saavedra (2009), Martínez-Chicón (2015) in the United States, because they particularly address the selected case studies. 
cit ways- mechanisms that construct difference and that reproduce inequality based on both the on the concepts of "race" and "ethnicity." That is to say, ways to manage cultural diversity labeled to be "intercultural" which contribute to the construction of ethno-cultural borders, and the creation of differences and inequality between groups.

We decided to examine these two theoretically distinct examples precisely because we are not planning to compare them to one another. We have selected two cases that are particularly significant in each analyzed contexts ${ }^{4}$, because through them, we have seen how, despite changes in the conceptualizations, both academics and politicians continue to construct "otherness" through cultural categorizations and hierarchies, and occasionally based on erroneous and static (in Spain) or even biologist (US) concepts of culture.

Although we cannot consider this text to be the result of a multi-local or multi-situational ethnography, it does share many of the premises (and some of the limitations) of this sort of approach, because it is not intended to draw a contrast between the two places, but means to establish a relationship between them. Thus, it is not so much a study of the places, as an analysis of the relationship between the places (Sinatti, 2008). In this sense, it is important to note what is the analysis of each of the cases.

We understand that a multi-sited ethnography cannot be reduced to a summary of various comparative perspectives, nor is it a distinct type of comparison (Marcus, 2001). The variety of locations and places where the research is conducted and the number of sites investigated is less important than the relationship that exists between these locations (Moraes, 2010) so as to allow the subject matter to be addressed in a complex and sophisticated manner. In this respect, we believe that the addition of these two specific cases allow us to sufficiently understand the relationship between the two places.

The multi-situated ethnography does not imply simultaneity. Although this has at times been seen as a limitation, for which solutions have been proposed (Marcus, 2001; Hannerz, 2003). For our research purposes, this is not a problem, as we are two researchers in two different places and contexts. Reflecting on the issue of depth, our aim is not to understand the complete social and cultural reality, but to have a more holistic view of those aspects that make up our research object.

Because the process of constructing research objects play with many variables, we should speak of "multiple identities, multiple objects, and multiple sites" (Dumont, 2012: 69). This is the case of the discussion at hand, in which the result is partly individual, and partly multiple (Lahire, 2004), and shared. As such, our theoretic objects of research are the construction of difference and the management of diversity.

We now move on to analyze the management of so-called "intercultural" strategies in the context of the United States and Spain, and the construction of difference. We begin looking within the context of education (Spain) and then continue with health (United States).

4- In the ethnographic researches, both on the Education in Spain (Primary and High School) and the health in the USA (Primary care and Nursing), result of studies that will be detailed later, the ethnography techniques have been used emphasizing the interviews and participant observation. 


\section{Description of each context and case study}

\subsection{The Spanish case: management of cultural diversity in the field of Education ${ }^{5}$}

With respect to the Spanish context, the attribution of categories that generate the construction ethnocultural boundaries are particularly visible when references are made to "immigration" and "foreigners". Public institutions (Fernández and García, 2015; Olmos-Alcaraz, 2016; Ortiz, 2015; Poveda, Jociles and Franzé, 2014), the media (García, Granados, Olmos-Alcaraz et al., 2014; Matínez and Olmos-Alcaraz, 2015), politicians (Fernández-Suarez, 2015; Olmos-Alcaraz, 2012; Sebastiani, 2015) and society together play a fundamental role in the construction of difference, by how they define who are "foreign immigrants," often conflated under the term "immigrant". When we talk about immigration in the context of the existing collective imagination, there is only one type of immigration: Never internal immigration, or immigration within the boundaries of a state, and never immigration from "rich" countries. That is to say, a citizen with German residency who lives in Costa del Sol and who runs a café is not considered by Spanish society to be an "immigrant." We are speaking, of course, of social categories, not -in this case, at least- demographic categories. The German citizen will not be considered a "foreigner", by which "foreigner" carries a negative and stigmatized connotation often attributed to the category of "immigrant".

But why do these categories - "immigration" and "foreignness"- in the current Spanish context create and recreate ethno-cultural boundaries? It certainly has to do with how migration has been problematized in recent decades in the country (Olmos-Alcaraz, 2015; Santamaria, 2002; Van Dijk, 2009; Zapata, 2001, 2016). Thus it appears that the Spanish national identity is defined in contrast to those who are categorized as "immigrants". EU citizens (with a nationality of any country in the European Union) escape the process of categorization, possibly -among other reasons- for the fallacy orchestrated by the EU community institutions of a supposed common European identity (bordering on citizenship). There are exceptions: For example, the Roma. The explanation for this is related, again, to the attribution of a negative and fairly widespread stereotype that "all Romanians are Gypsies" in a context where racism against the gypsies has been historically constant and even until today, still unsurpassed (Calvo, 1990; Checa and Arjona, 2009).

When we look at how these categories function in the educational sphere, what we see is a reproduction of the logic of the problematization of migration, but in schools. When students categorized as an "immigrants" begin to become visible in Spanish schools, their presence is used as a justification to perform "old" problems in the educational system with a long historical presence from a new perspective. In other words, questions about the lack of resources (both economic and of professional variety), the

5- The ideas in this text are part of the analysis made in the projects entitled "School successes and failures. Sociocultural paths of foreign immigrants and native pupils in the Andalusian educational system" (Ministry of Science and Innovation, National Plan for I+D+i (Research, Development and Innovation), 2010-2013), "Multiculturalism and integration of the foreign immigrant population in the Andalusian schools" (Andalusian Administration, Excellence Project, 2007-2010), "Assessment of the educational assistance initiatives for immigrant students in Andalusia" (Andalusian Administration, 2004-2006) and "Building differences at school. Studies of the ATAL (Spanish acronym for Linguistic Adaptation Temporary Classrooms) paths in Andalusia, of the teachers and the pupils" (Ministry of Science and Innovation, National Plan for I+D+i (Research, Development and Innovation), 2014-2016. 
failure of schools, neglect or loss of quality in education are reinterpreted and blamed on the presence of students identified as immigrants; are blamed on the presence of a "new diversity" (though now, for quite some time present) in the classrooms. In reality, diversity has always been approached as a problem in the Spanish school system, and the solution has always been understood -and continues to be understood- as homogenization; that is to say, assimilation into the "culture" of the dominant group, in this case, "school culture".

Despite the official statements, political declarations and writings around political policies declared to be "intercultural", which claim a level of interculturalism that justifies the deproblematization of the issue, and praises the value of diversity, the observed reality is quite different (Olmos-Alcaraz, 2010, 2016). When an educational policy is said to be intercultural, it often prioritizes the intervention of some groups over others, (or in this case, the immigrant group, rather than the entire population -as though only immigrants are considered intercultural-), the policy in fact is laying the base for the construction of difference between groups, and strengthening the ethnic-cultural boundaries between them. Thus, it is remarkable that so-called intercultural education works, first and foremost, to teach the language of instruction to groups of immigrant students (Garcia et al., 2007); the "other" languages are addressed residually (Franzé, 2008; Mijares, 2011; Olmos-Alcaraz, 2016); the content of the curriculum remains remarkable monocultural (Olmos-Alcaraz, 2010; Rubio, 2013); and the diversity provided by immigrant students is visible only sporadically in school folkloric events (Garcia et al., 2007; Leiva, 2012; OlmosAlcaraz, 2010; Olmos-Alcaraz and Contini, 2016). That is to say, it is an intercultural approach that seems to respond primarily to the interests of the institutions of the dominant groups, and the interests of a state that continues to seek homogeneity, and the disappearance and deletion of heterogeneity.

\subsection{The United States case: management of cultural diversity within the field of Health ${ }^{6}$}

The problematization of immigration has also been a continuum in the context of the United States, especially in terms of identity and safety within national health. A study conducted in 2003 in California (NCM and Bendixen and Associates, 2009), the year that more than $25 \%$ of the state's population was foreign born (Figueroa and Saavedra, 2009), found health -and language barriers associated with accessing it- to be one of the biggest concerns and needs described by immigrants, even ahead of employment and education.

In this sense, it is not so strange that in the United States, the majority of the cases that attempt to address cultural diversity have been in the health field. Similarly, it isn't surprising that most measures and programs considered to be "best practices" with regard to the development of intercultural competencies are in the health industry, including a wide range of mental health and social services (American Public Health Association, 2015; California Health Worker Alliance, 2013; Centers for Medicare and Medicaid Services, 2015). Likewise, people working in the fields of health and social services have also written

6- The ideas in this text are part of the analysis of the intercultural training of employees of public administrations in Andalusia and California, developed in collaboration with the University of Granada (Institute of Migration) and the University of California, San Diego (Center for Comparative Immigration Studies), and funded by the Ministry of Education, Culture and Sports, through the National Program of Mobility of Human Resources of the National Plan of I-D 2008-2011 extended by agreement of the Council of Ministers of 7 October 2011. 
most of the manuals and guides on skills development in the context of cultural diversity (Anderson, 2013; Rosenthal, Rush and Allen, 2016; Soliz and Giles, 2014).

The provision of the first language services arose from needs described by professionals and entrepreneurs in the field of health, who demanded equal access to quality health services (Figueroa and Saavedra, 2009). Later, new foreign-born users living in the United States, who were blocked from being consumers of health services due to language barriers, also complained, adding their voices to the concerns already raised by businesses and healthcare professionals.

Here there is an important difference between Spain and the United States with respect to intercultural policies, services, and delivery groups. In the Spanish case, most of the foreign immigrant population has come to be considered a "user group" of social services and compensation policies, while in the case of the United States, the "user groups" are considered, drawing on the mercantilist concept, to be "customers". Still, with the goal of quality access to health, and a population that is increasingly diverse -in terms of ethnicity, language, and race- with distinct histories, profiles, types of treatment, conceptions of health and disease types and access to health services in their countries of origin, it was necessary to begin to make changes that would allow true access to health.

Thus the first intercultural service, which Qureshi and Callazos (2006) term "structural competence" offered was the incorporation of translators; and in the second stage, staff training in language skills and the recruitment of workers with the same mother tongue and "ethnic affiliation" with the patients that made up the largest group of immigrants in their respective areas. These new professional recruited to fill the objective of attending to an increasingly diverse population, however, generally occupied less-skilled labor positions, such as administrative and informational positions, or in some cases, in the infirmary. There also exist -albeit in a much lower percentage- health professionals with specialties in various areas who have nationalities other than American, or who are American nationals but are ethnically distinct from the majority group.

The case of mental health and social work is an exception. In these areas, programs in intercultural competencies are quite common. In fact, the first educational programs instructing about cultural diversity arose within the context of mental health and educational services (particularly higher education), and these sectors continue to be pioneers in providing intercultural programs. Therefore, it's relatively common to find people not belonging to the "white" majority group in positions of expertise, responsibility and leadership among the specialized personnel in this field. In most cases, this fact is explained by hospitals and health centers to be because of the experience of the personnel, and because of the availability of economic resources allotted towards cultural diversity.

However, this is not the reality in other health fields, such as primary care, which is considered the gateway to health services. Still, it is not surprising that sometimes, especially in areas such as the San Diego border with Mexico, the country of origin of the largest group of foreigners in California, the patient is administratively attended from the moment that they arrive at reception to discuss their health issues in their native language. However, this reality changes the moment they are examined by a trained health professional, who usually tends to be a doctor who only speaks English, even in health centers where the majority of the patient population speaks Spanish.

But, as happens in Spain, it is not always clear what -or for whom- it means to be "culturally diverse" (Martínez-Chicón, 2012, 2014). In some cases, diversity is associated with the passport, but in general it's ascribed to ethnic diversity and people who have been "racialized" based on phenotypic and linguistic 
criteria. This also works in reverse; It's not unusual to find cases in which health staff address patients in the language of the group they suppose the individual to be a part of, based on certain racial criteria.

One example of this is the establishment of questionnaires and in the type and relation of the described categories, that people need to fill out in order to be attended in health centers. With regard to ethnicity and language, we find the following categories:

PRINCIPAL LANGUAGE: 1) English, 2) Spanish, 3) Sign Language, 4) Other

ETHNICITY: 1) Unknown, 2) Hispanic, 3) Non-Hispanic

The questionnaire assumes that the ethnic category of "Hispanic" is sufficiently representative that it alone accounts for half of the possibilities in which someone can be incorporated. The other half is able to combine all kinds of different ethnicities. It is assumed that, in this case, the most adscriptive element would be the language, however, there is a significant arbitrariness when opting for one or the other. If a person of Spanish nationality were to go for public services, and was forced to opt for one of these options, one would think there would be more listed than Hispanic and non-hispanic, even though the only language options were Spanish and English.

\section{Discussion and final remarks}

While, as we have already discussed, the examples of education and health and the contexts of Spain and the United States are distinct and seemingly incomparable, the reality of how we approached each analysis shows us that there exists a common dynamic of logical processes, such as recognition of cultural diversity defined as "intercultural", which builds ethno-cultural boundaries that create differences and inequality between groups that are still repeatedly essentialized. These processes, far from narrowing the gap, help to maintain the distance between "us" and "them" based on various convoluted and sometimes disparate was of attributing "ethnic" and "racial" labels, that rarely take into account the variety of identity variables.

In the Spanish context, and in relation to the case study noted, the category of "immigrant" operates in a variety of ways with respect to the creation of ethno-cultural barriers. In the first place, we see this with how schools operate, regarding the allocation of human and financial resources, to meet diversity requirements from immigrants enrolled in school. In the case of Andalusia -although it also occurs similarly in other autonomous communities- most resources (both financial and in terms of personnel) mobilized in this regard are Temporary Schools for Linguistic Adaptation (ATAL). ATAL is a measure, within educational policies considered intercultural, that consists of the provision of teachers specializing in teaching Spanish as a foreign language for centers that request it. The teachers also occasionally play other roles, such as providing advice to other educators with regards to intercultural materials. In order to take advantage of this aid, centers need to have a certain number of students that need the services ATAL offers. In other words, if the center can demonstrate to the educational administration that they have a significant percentage of students who do not speak Spanish, or that have difficulties with the language, the center can solicit help from ATAL teachers.

Still, the centers do not count students who are "linguistically incompetent," they count the number of "foreign immigrants". Again, "immigration" and "foreignness" appear very closely related, because 
although in reality students with foreign nationalities are counted, not all would need an ATAL teacher. In the case of British students, for example, whose mother tongue in the majority of cases is English, the teachers tend to prefer other options for managing diversity: Rather than asking for teachers of Spanish as a second language, they request to be converted into bilingual "Spanish/English" centers. This allows us to see the emergence of a logic of attribution of meaning, in which "what language they speak" can place the student on one or another side of the border between "us" and "them". This being so, it is more "other" if one speaks Chinese, Arabic or Wolof than if one speaks English or German.

The second example that we wish to explore is how the category of "immigrant" is articulate in educational contexts, in manners which contribute to the reinforcement of determined ethno-cultural categories, and which have to do with the attributions made about the scholastic performances of individuals identified within each group. Again, we must return to the intercultural approach within the educational context of Spain. We have already mentioned the assimilationist character of it, notably in the priority given to teaching Spanish as a foreign language at the expense of other important issues. It is also worth remarking upon what this balancing approach reveals about their perspective on diversity. The underlying assumption of this approach is to understand diversity as a handicap, leading to take those who are different with respect to the majority group as having some intrinsic learning disability. Clearly, the problems created by the lack of common language -rather, the language of the school- is self-explanatory, in that it creates challenges with regard to following a standardized manner in class. However, in many cases, this is confused with cognitive or learning difficulties, in such a way as to prevent the student from participating in activities where the school's language of instruction is, in a way, secondary. We refer to more instrumental activities like math, where communication is based on numerical operations, for example. Even so, the representation of immigrant students continually reinforce otherness in this too. The immigrant student is often treated as a problem student, with special educational needs beyond the realm of language school, a "bad student" (Olmos-Alcaraz and Rubio, 2013). In this sense, there is a widespread idea if the student population extends beyond a certain determined percentage, the academic level of the school will decrease, even though there do not exist any investigations that confirm this notion. Again, it is a perception of the diversity "problem". In this sense, it is revealing that when the teaching methodologies are adapted to the existing diversity, one sees that exactly the opposite is true: The academic level of the students increase. We have the example of schools employing more cooperative ways of working with their students, where the more advanced children help their struggling peers. That is to say, if we consider that we learn the most when we teach others we know that diversity in the classroom is no longer a problem, but an opportunity to improve. This is something that is ignored when it is said that diversity in the classroom causes a decline in the quality of education.

We observe something similar in the American context with relation to the questions posed by the profiles of immigrants based sometimes on nationality, others on language, and others on phenotypic features, and on occasions combinations of all of the above factors. Here also "immigration" and "foreignness" appear to be closely related and, again, we encounter the contradiction between the opportunity to improve and how to compensate for problems within the health field.

Whether diversity is considered to be an opportunity or a problem depends largely on whether or not the "immigrant" or "foreign" patients are considered to be closer or further from "us". In the positive sense, such diversity could be seen as an opportunity to diversify the profile of health professionals, im- 
prove understanding, intervention strategies, and improve the quality of overall healthcare. But it could also be a problem to compensate for existing difficulties in understanding different conceptions of health and disease, potential importers of new diseases, if patients are among those "more different." Also, with regards to whether they are considered clients or users.

Both of these are examples that demonstrate how to manage processes considered "intercultural", that illustrate that basing a policy on the recognition of cultural diversity, without properly contemplating the correct variables of identity, and the power relations that exist between groups, stem from differences that create and reproduce inequality. It is important therefore to try to find ways of managing diversity that understand this difference, and value without prioritizing the different groups.

\section{References}

American Public Health Association. 2015. Community Health Workers. In American Public Health Association.

Anderson, Lanette. 2013. Understanding the different scopes of nursing practice. December, 16.

Barth, Frederik. 1969. Introducción. In Los grupos étnicos y sus fronteras. La organización social de las diferencias culturales, edited by Frederik Barth. Mexico: FCE, 9-49.

California Health Worker Alliance. 2013. Taking innova on to scale: Community health workers, promotores, and the triple aim. CHWA; August.

Calvo, Tomás. 1990. ¿España racista?: voces payas sobre los gitanos. Barcelona: Anthropos.

Centers for Medicare and Medicaid Services. 2015. State innovations models initiatives: General information. August, 25.

Checa, Juan and María Angeles Arjona. 2009. Procesos de segregación residencial en la población gitana: el caso almeriense. Revista de Estudios Regionales 85: 173-196.

Devalle, Susana. 2002. Etnicidad e edentidad: usos, deformaciones y realidades. In Identidad y etnicidad: continuidad y cambio, edited by Susana Devalle. Mexico: Colegio de México and CEAA, 11-29

Dietz, Gunther. 1999. Etnicidad y cultura en movimiento: desafíos teóricos para el estudio de los movimientos étnicos. Nueva Antropología, 17 (56): 81-107.

Dietz, Gunther. 2012. Multiculturalismo, interculturalidad y diversidad en educación: una aproximación antropológica. Mexico: Fondo de Cultura Económica.

Dumont, Guillaume. 2012. Multiplicidades móviles, dibujo de una pluralidad situacional. Encrucijadas. Revista Crítica de Ciencias Sociales, 4(2): 66-80.

Fernández, José and Francisco García. 2015. El desarrollo normativo que regula las aulas para escolares de nacionalidad extranjera. Profesorado. Revista de Currículum y Formación del Profesorado, 19 (1): 468-495.

Fernández-Suárez, Belén. 2015. El discurso político de integración de los inmigrantes en el nivel regional en España: la división entre políticas de identidad y políticas sociales. Tomo, 26: 37-65. http://dx.doi. org/10.21669/tomo.v0i0.4402

Figueroa-Saavedra, Miguel. 2009. Estrategias para superar las barreras idiomáticas entre el personal de salud usuario de servicios de salud pública en España, Estados Unidos y México. Nueva época, 12: 149-175. 
Franzé, Adela. 2008. A la sombra del origen: lengua, cultura e identidad en los fundamentos de la ELCO. In ¿Es la escuela el problema?: perspectivas socio-antropológicas de etnografía y educación, edited by María Isabel Jociles and Adela Franzé. Madrid: Trotta, 260-274.

Geertz, Clifford. 1973. La interpretación de las culturas. Barcelona: Gedisa.

Hannerz, Ulf. 2003. Being there...and there...and there! Reflections on multi-site ethnography. Ethnography 4 (2): 201-216.

Lahire, Bernad. 2004. El hombre plural. Los resortes de la acción. Barcelona: Bellaterra.

Leiva, Juan. 2012. Aportaciones y reflexiones pedagógicas sobre educación intercultural: de la diversidad cultural a cultura de la diversidad. Qurriculum: Revista de Teoría, Investigación y Práctica Educativa 25: 57-75. Marcus, George. 2001. Etnografía en/del sistema mundo. El surgimiento de la etnografía multilocal. Alteridades, 11 (22): 111-127.

Martínez-Chicón, Raquel. 2012. Aprendiendo a gestionar la diversidad en las administraciones públicas. Paper presented in I Congreso Internacional sobre Migraciones en Andalucía, Granada.

Martínez-Chicón, Raquel. 2014. Servicios sociales y administraciones públicas "culturalmente competentes". Procesos de formación, evaluación y transferencia. Paper presented in Congreso Internacional de Facultades y Escuelas de Trabajo Social, Murcia.

Martínez-Chicón, Raquel. 2015. Universidad: interculturalidad en la formación, eficacia en la profesión. Opción, 31 (6): 511-524.

Martínez, María and Antonia Olmos-Alcaraz. 2015. Menores y mujeres inmigrantes en la radio y la televisión públicas: imágenes sesgadas y ficciones mediáticas. Revista Tonos Digital, 29: 1-22.

Mijares, Laura. 2011. El programa de enseñanza de lengua y cultura de origen (ELCO) marroquí. In Población inmigrante y escuela: conocimientos y saberes de investigación, edited by Javier García and Silvia Carrasco. Madrid: MECD and IFIIE, 117-141.

Moraes, Natalia. 2010. La metodología de investigación multisituada en el análisis del transnacionalismo migrante. Paper presented in X Congreso Español de Sociología, Madrid.

NCM and Bendixen \& Associates. 2003. Bridging language barriers in health care: Public opinion survey of California immigrants from Latin America, Asia and the Middle East. Executive summary. In <http:// www.ncmonline. com/media/pdf/tce_summary.pdf $>$.

Olmos-Alcaraz, Antonia. 2010. Construcción discursiva del alumno inmigrante extranjero en Andalucía: el otro en nuestras escuelas. Revista de Educación, 353: 469-493.

Olmos-Alcaraz, Antonia. 2012. Discurso político e inmigración: análisis crítico de discurso a propósito de la reforma gubernamental realizada al sistema de salud pública en España. Disucurso \& Sociedad, 6 (4): 739-758.

Olmos-Alcaraz, Antonia. 2015. Análisis crítico de discurso y etnografía: una propuesta metodológica para el estudio de la alteridad con poblaciones migrantes. Empiria. Revista de Metodología de Ciencias Sociales, 32: 103-128. http://dx.doi.org/10.5944/empiria.32.2015.15311

Olmos-Alcaraz, Antonia. 2016. Diversidad lingüístico-cultural e interculturalismo en la escuela andaluza: un análisis de políticas educativas. RELIEVE, Revista Electrónica de Investigación y Evaluación Educativa, 22 (2): 1-20. http://dx.doi.org/10.7203/relieve.22.2.68.32

Olmos-Alcaraz, Antonia and Pierangela Contini. 2016. Las ausencias del paradigma intercultural en España en contextos urbanos multiculturales. Revista Mexicana de Sociología, 78 (4): 685-711. 
Olmos-Alcaraz, Antonia and María Rubio. 2013. Corporalidad del «buen estudiante»: representaciones de género, «raza», etnia y clase social en la escuela española. Revista Iberoamericana de Educación, 62: 163-179.

Ortiz, Mónica. 2014. Inmigración, escuela y exclusion. Empiria: Revista de Metodología de Ciencias Sociales 28: 59-78. http://dx.doi.org/10.5944/empiria.28.2014.12121

Poveda, David, María Isabel Jociles and Adela Franzé. 2014. Immigrant students and the ecology of externalization in a secondary school in Spain. Anthropology \& Education Quarterly, 45 (2): 182-202. https://doi.org/10.1111/aeq.12058

Qureshi, Adil and Francisco Collazos. 2006. El modelo americano de competencia cultural psicoterapéutica y su aplicabilidad en nuestro medio. Papeles del Psicólogo, 27 (1): 50-57.

Restrepo, Eduardo. 2004. Teorías contemporáneas de la etnicidad: Stuart Hall y Michel Foucault. Popayán: Editorial Universidad del Cauca.

Restrepo, Eduardo. 2013. Etnización de la negridad: la invención de las 'comunidades negras' como grupo étnico en Colombia. Popayán: Editorial Universidad del Cauca.

Rex, John. 1995. La metrópoli multicultural: la experiencia británica. In Culturas, estados, ciudadanos: una aproximación al multiculturalismo en Europa, edited by Emilio Lamo de Espinoza. Madrid: Alianza, 197-223.

Rosenthal, Lee; Rush, Carl; Allen, Caitlin. 2016. Understanding scope and competencies: A contemporary look at the United States community health worker field, progress report of the community health worker (CHW) core consensus (C3) Project: Building National Consensus on CHW Core Roles, Skills, and Qualities.

Rubio, María. 2013. Construyendo diferencias desde retóricas de la igualdad. El caso del alumnado denominado latinoamericano en la etapa de educación secundaria obligatoria Doctoral Tesis, Granada: Universidad de Granada.

Sebastiani, Luca. 2015. Mirando a través de la burbuja: Representaciones de la migración no comunitaria en los discursos de actores políticos y sociales de la Unión Europea. Revista Crítica de Ciências Sociais, 108: 31-54.https://doi.org/10.4000/rccs.6085

Sinatti, Giulia. 2008. Migraciones, trasnacionalismo y locus de investigación: multi-localidad y la transición de "sitios" a "campos". In Nuevos retos del transnacionalismo en el estudio de las migraciones, edited by Carlota Solé, Sonia Parella and Leonardo Cavalcanti. Madrid: Ministerio de Trabajo e Inmigración, 91-111.

Smith, Anthony. 1997. La identidad nacional. Madrid: Trama Editorial.

Soliz, Jordan and Howard Giles. 2014. Relational and identity processes in communication: A contextual and meta-analytical review of communication accommodation Theory. In Communication yearbook 38, edited by E. Cohen. Thousand Oaks, CA: Sage, 106-143.

Stavenhagen, Rodolfo. 1991. Los conflictos étnicos y sus repercusiones en la sociedad internacional. RICS, 43(1): 1-20.

Taylor, Charles. 1996. Etnia. In Diccionario de Etnología y Antropología, edited by Pierre Bonte and Michel Izard, Madrid: Akal, 258-260.

Van Den Berghe, Pierre. 2002. Fundamentos sociobiológicos de la etnicidad. In Razas en conflicto. Perspectivas sociológicas, edited by Eduardo Terrén. Barcelona: Anthropos Editorial, 220-233. 
- Revista de Ciencias Sociales y Humanidades. ISSN-P: 0188-9834 ISSN-E: 2395-8669.

Van Dijk, Teun Adrianus. 2009. Discurso y poder. Barcelona: Gedisa.

Weber, Max. 2002. Las comunidades étnicas y la conciencia de raza. In Razas en conflicto. Perspectivas sociológicas, edited by Eduardo Terrén. Barcelona: Anthropos Editorial, 72-85.

Wieviorka, Michel. 1992. El espacio del racismo. Barcelona: Paidós.

Wieviorka, Michel. 2006. La mutación del racismo. Migraciones, 19: 151-163.

Wieviorka, Michel. 2014. Les mutations du racisme contemporain. In Identities on the move, edited by Peter Lang. Bern: Editions Flocel Sabaté, 503-515.

Zapata, Ricard. 2001. Fundamentalismo estatal de la UE en torno a la inmigración. Revista CIDOB d'afers internacionals, 53: 149-176.

Zapata, Ricard. 2016. Exploring the foundations of the intercultural policy paradigm: a comprehensive approach. Identities 23 (2): 155-173. http://dx.doi.org/10.1080/1070289X.2015.1006523 